\title{
A NEW SPECIES OF ORNITHOBOEA (GESNERIACEAE) FROM VIETNAM
}

\author{
D. J. Middeton ${ }^{1} \&$ NGoc $\mathrm{SAM} \mathrm{LY}^{2}$
}

A new species of Gesneriaceae, Ornithoboea emarginata D.J.Middleton \& N.S.Ly, is described from Vietnam. A proposed IUCN conservation assessment is provided.

Keywords. Gesneriaceae, new species, Ornithoboea, Vietnam.

\section{INTRODUCTION}

There is an area of karst limestone in Kien Giang Province of Vietnam located in the southwest of the Mekong basin, straddling the border between Vietnam and Cambodia. It consists of a number of small, strongly karstified and isolated hills, and features a dramatic landscape with peculiar vegetation that is unknown in other parts of southern Vietnam or Cambodia. Since 1993 numerous species new to science and currently endemic to the Kien Giang hills have been discovered in caves and soils of the area and more are yet to be found (Deharveng et al., 1995; Vermeulen et al., 2007). Even new genera and supra-generic taxa of beetles and springtails have been collected, making the Kien Giang hills the richest hot-spot of endemism for deep soil fauna known in the tropics (L. Deharveng, pers. comm., 2004). Many plant taxa found in Kien Giang are extremely interesting, both in Southeast Asia and the rest of the world, including the recently described Begonia bataiensis Kiew (Truong et al., 2005).

The Institute of Tropical Biology in Ho Chi Minh City is currently carrying out a project in the south of Vietnam funded by the MacArthur Foundation. Part of this research project is an exploration of karst limestone areas of Kien Giang Province. During recent field work by the second author in this area a previously undescribed species of Ornithoboea Parish ex C.B.Clarke was collected. This is described here as new.

The last revision of Ornithoboea was by Burtt (1958). It included 10 species, one of which, Ornithoboea leptonema B.L.Burtt, was described from Tonkin, Vietnam. According to Burtt (1958) the material of Ornithoboea parishii C.B.Clarke from

\footnotetext{
${ }^{1}$ Royal Botanic Garden Edinburgh, 20A Inverleith Row, Edinburgh EH3 5LR, Scotland, UK. E-mail: d.middleton@rbge.ac.uk

${ }^{2}$ Institute of Tropical Biology, 85 Tran Quoc Toan Street, Dst 3, Ho Chi Minh City, Vietnam. E-mail: sahucultura196@yahoo.com
} 
Vietnam (Pellegrin, 1930) may also be this species. Since Burtt (1958) three more species have been described (Li, 1983; Burtt, 2001), none of them from Vietnam.

\section{Ornithoboea emarginata D.J.Middleton \& N.S.Ly, sp. nov. Figs 1, 2.}

$\mathrm{Ab}$ Ornithoboea lacei Craib foliorum basibus persistentibus brevibus duris in surculis vetustioribus carentibus, folii margine multo magis irregulariter dentato, antheris pilosis et fructibus brevioribus differt. Ab Ornithoboea wildeneana Craib folii margine, corollae lobis emarginatis et fructibus minoribus recedit. - Type: Vietnam, Kieng Giang Province, Kien Luong District, Hang Ca Sau Hill, 14 vii 2007, N.S. Ly et al. 094 (holo E; iso Institute of Tropical Biology in Ho Chi Minh City).

Herb growing from fissures in karst limestone; stem $20-80 \mathrm{~cm}$, glandular pubescent, leaf internodes $2.2-3 \mathrm{~cm}$. Leaves opposite, those of a pair slightly unequal; petiole 2.5-8.6 cm long, densely glandular pubescent; blade very thin, ovate to elliptic, $3-11 \times 2.4-7.3 \mathrm{~cm}$, apex obtuse, base slightly unequal, rounded to cordate, margin irregularly weakly and strongly dentate; $8-11$ pairs of secondary veins, tertiary venation reticulate; glandular pubescent above, more densely so beneath with hairs of various sizes and lengths throughout. Inflorescences $3.3-8 \mathrm{~cm}$ long, densely glandular pubescent throughout; peduncle 6-16 mm long; pedicels 12-16 mm long. Sepals narrowly elliptic, $8.5-9 \times 2-2.5 \mathrm{~mm}$, apex shortly acuminate, sparsely glandular puberulent. Corolla bilabiate, lower lip longer, glabrous outside except lobes ciliate; tube $6 \mathrm{~mm}$ long, somewhat inflated; upper lip slightly 2-lobed, somewhat erect to slightly reflexed, each lobe slightly notched towards its sinus side, c. $4 \mathrm{~mm}$ long, with a ring of hairs on the ridge of tissue at the base of this lip which runs down to the sinus with the lower lip (see Burtt (1958) for an explanation of the characteristic corolla structure and pubescence in the genus); lower lip 3-lobed, c.10.5 mm long, pubescent on the interior face of the common part of the lip, each lobe c.3.2 $\times$ $3.8 \mathrm{~mm}$, distinctly notched at each apex. Stamens with a pronounced sterile projection; filament $1.5 \mathrm{~mm}$ long; projection $1.7 \mathrm{~mm}$ long; anthers $1.8 \times 2.5 \mathrm{~mm}$, densely hairy, at least around base; staminodes 3, two of which $1.5 \mathrm{~mm}$ long, the third $0.2 \mathrm{~mm}$ long. Ovary $1.8 \times 1.5 \mathrm{~mm}$, densely glandular puberulent; style $9 \mathrm{~mm}$ long, glandular puberulent. Fruit 6-7 $63 \mathrm{~mm}$, twisted, densely pubescent.

Distribution. Endemic to Hang Ca Sau (Crocodile Cave) Hill, Ba Tai Hill and Bai Voi (Mo So) Hill, about $3 \mathrm{~km}$ NNW of Hon Chong, Kien Luong District, Kien Giang Province, SW Vietnam (Fig. 2). This species was first discovered in fruit by N.S. Ly et al. in December 2006 on Hang Ca Sau Hill, recollected there in flower in July 2007, and has been recently recorded on Ba Tai Hill (in July 2007) and on Bai Voi (Mo So) Hill (in August 2007).

Habitat and ecology. Grows in fissures or small soil pockets on erect cliffs or in cave mouths on limestone rocks at 10-50 m altitude, usually shaded. Flowering in July to October and fruiting in September to December. 


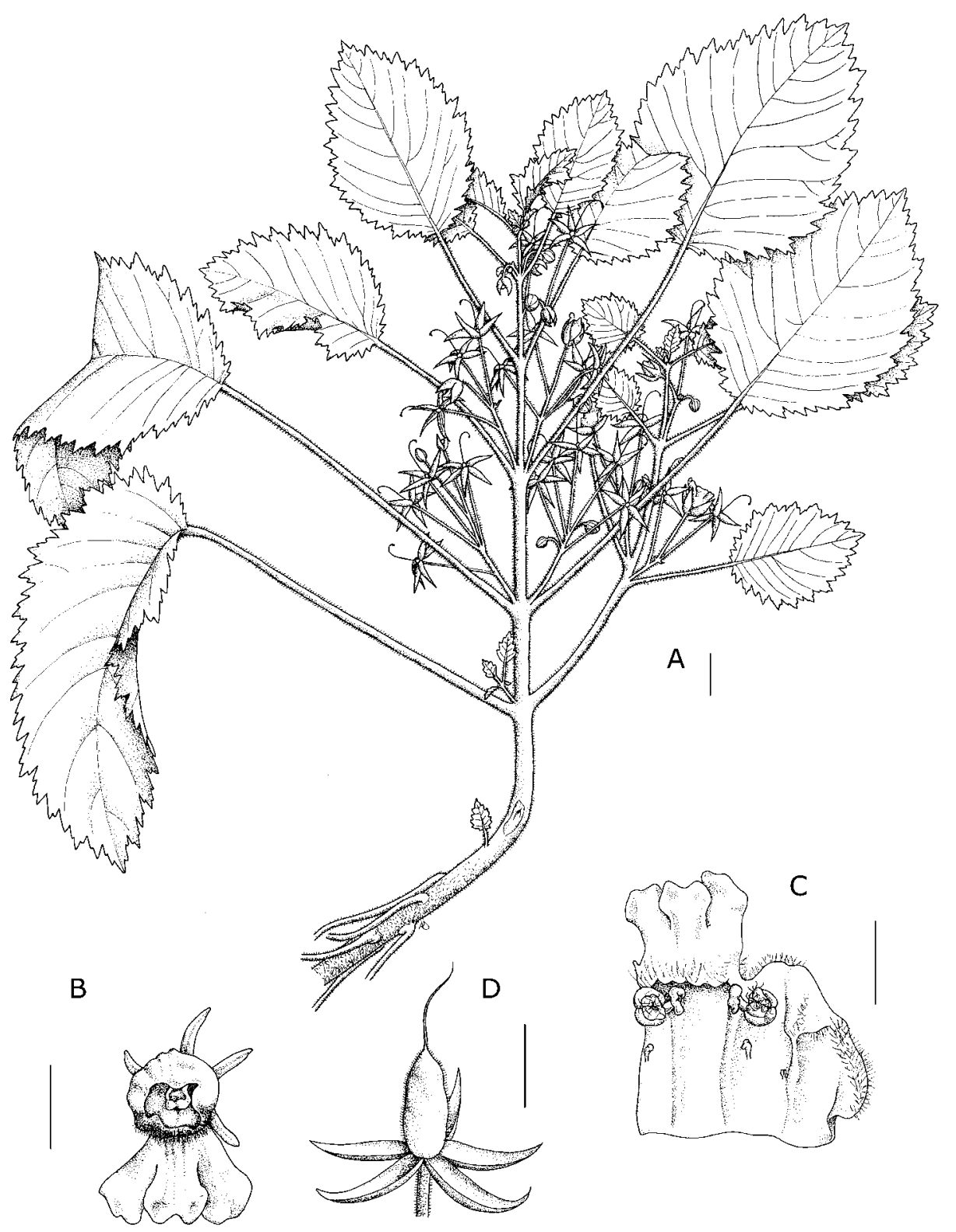

FIG. 1. Ornithoboea emarginata D.J.Middleton \& N.S.Ly. A, habit; B, flower; C, flower dissection (split along one of the lines between the upper and lower lips); D, fruit. Scale bars: $\mathrm{A}=1 \mathrm{~cm} ; \mathrm{B}-\mathrm{D}=5 \mathrm{~mm}$.

IUCN conservation assessment. Vulnerable (VU D2) (IUCN, 2001). This species occupies less than $20 \mathrm{~km}^{2}$ and there are threats to the limestone habitats in this area. Although some of the area is under legal protection, and was recently recognised as a biosphere reserve (Kien Giang Biosphere Reserve, in 2006), many of the limestone 


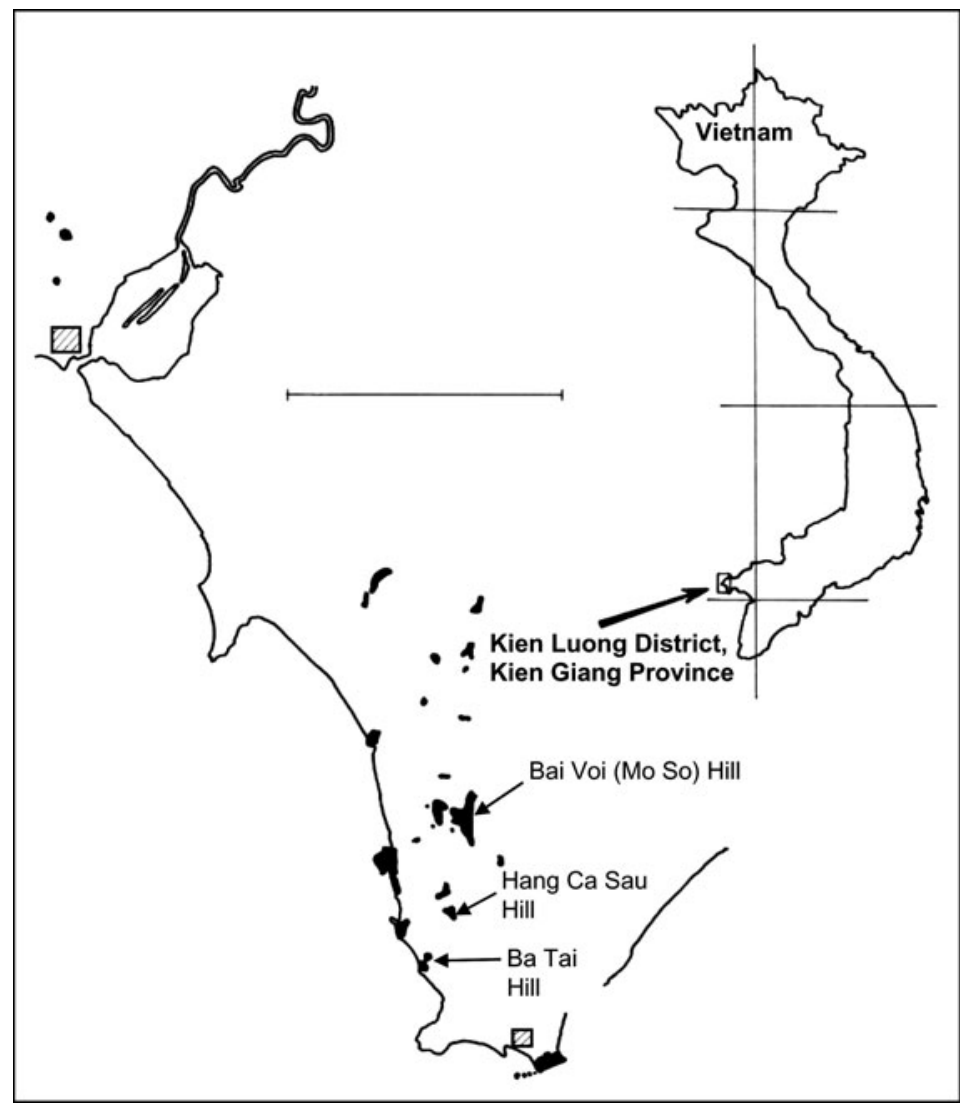

FIG. 2. Distribution of Ornithoboea emarginata D.J.Middleton \& N.S.Ly.

karsts of Kien Giang have suffered from human impacts such as small scale agriculture, silviculture and shrimp farming at the foot of the hills. In at least one of the dolines there has been firewood collection, the caves are sometimes used, and there have been problems with alien species. Lime exploitation and cement production have been especially devastating. Bai Voi Hill is scheduled for quarrying, with about two-thirds of the hill to be exploited for cement production (Truong et al., 2005). By the time the limestone exploitation contract is completed, less than $3 \mathrm{~km}^{2}$ in several separate limestone blocks will be left in the Vietnamese portion of the karst, making the Kien Giang hills the most threatened karst ecosystem in the world (Truong et al., 2004). Ornithoboea emarginata is therefore vulnerable due to its narrow distribution and small population size.

Additional specimens examined. Vietnam. Kien Giang Province: SE slope of Hang Ca Sau Hill, $10^{\circ} 11^{\prime} 46.0^{\prime \prime} \mathrm{N}, 104^{\circ} 36^{\prime} 43.5^{\prime \prime} \mathrm{E}, 10 \mathrm{~m}, 2$ xii 2006, N.S. Ly, C.K. Le \& Q.T. Truong 036 (E, Institute of Tropical Biology in Ho Chi Minh City); Ba Tai Hill, southern slopes of Ba Tai Hill, $10^{\circ} 10^{\prime} 23.90^{\prime \prime} \mathrm{N}, 104^{\circ} 36^{\prime} 46.5^{\prime \prime} \mathrm{E}, 12$ vii 2007 , N.S. Ly 054 (Institute of Tropical Biology in 
Ho Chi Minh City); Bai Voi Hill, northern slopes, $10^{\circ} 13^{\prime} 17.50^{\prime \prime} \mathrm{N}, 104^{\circ} 37^{\prime} 12.90^{\prime \prime} \mathrm{E}, 19$ viii 2007, N.S. Ly 108 (Institute of Tropical Biology in Ho Chi Minh City).

This new species is most similar to Ornithoboea lacei Craib from Burma with which it shares the character of the emarginate corolla lobe apices. It differs from Ornithoboea lacei, however, in the lack of persistent short hard leaf bases in the older growth, the much more irregular dentate leaf margin, the hairs on the anthers, and the shorter fruits. It differs from Ornithoboea wildeneana Craib in its leaf margin, emarginate corolla lobes, and smaller fruits.

\section{ACKNOWLEDGEMENTS}

The authors should like to thank Prof. Le Cong Kiet and Truong Quang Tam for their advice on the living specimen collection. The field work was supported by the MacArthur Foundation funded project 06-86493. We wish also to thank Robert Mill for the Latin diagnosis, and Anna Dorward for the illustration.

\section{REFERENCES}

Burtt, B. L. (1958). Studies in the Gesneriaceae of the Old World. XI: The genus Ornithoboea. Notes Roy. Bot. Gard. Edinburgh 22: 287-299.

BurtT, B. L. (2001). Flora of Thailand: Annotated checklist of Gesneriaceae. Thai For. Bull. (Bot.) 29: 81-109.

Deharveng, L., Truong, Q. T. \& Duong, T. D. (1995). Explorations au centre et au sud du Vietnam. Spelunca 59: 8-10.

IUCN (2001). IUCN Red List Categories and Criteria, Version 3.1. IUCN Species Survival Commission. Gland, Switzerland and Cambridge, UK: IUCN.

LI, H-W. (1983). Notulae de Gesneraceis Yunnanensibus. Bull. Bot. Res., Harbin. 3(2): 1-55.

Pellegrin, F. (1930). Ornithoboea. In: Lecomte, M. H., Flore Générale de l'Indo-Chine 4: $550-552$.

Truong, Q. T., Le, B. T., Nguyen, P. N. \& Diep, D. P. (2004). Biodiversity in the limestone area of Ha Tien and Kien Luong, Kien Giang province. Proceedings of TransKARST 2004 International Transdisciplinary Conference on Development and Conservation of Karst Regions, Ha Noi, Vietnam, 13-18 September 2004.

Truong, Q. T., Kiew, R. \& Vermeulen, J. J. (2005). Begonia bataiensis, a new species in section Leprosae (Begoniaceae) from Vietnam. Gard. Bull. Singapore 57: 19-23.

Vermeulen, J. J., Phung, L. C. \& Truong, Q. T. (2007). New species of terrestrial molluscs (Caenogastropoda, Pupinidae \& Pulmonata, Vertiginidae) of the Hon ChongHa Tien limestone hills, Southern Vietnam. Basteria 71: 81-92. 